\title{
G

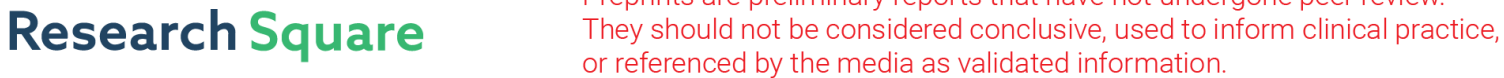

\section{Evidence for late glacial oceanic carbon redistribution and discharge from the Pacific Southern Ocean}

\section{Shinya Iwasaki ( $\sim$ siwasaki@marum.de )}

MARUM - Center for Marine Environmental Sciences, Universität Bremen

\section{Lester Lembke-Jene}

Alfred-Wegener-Institut Helmholtz-Zentrum für Polar- und Meeresforschung https://orcid.org/00000002-6873-8533

\section{Kana Nagashima}

Japan Agency for Marine-Earth Science and Technology

\section{Helge Arz}

Leibniz Institute for Baltic Sea Research https://orcid.org/0000-0002-1997-1718

\section{Naomi Harada}

Japan Agency for Marine-Earth Science and Technology https://orcid.org/0000-0002-2725-7346

\section{Katsunori Kimoto}

Research Institute for Global Change

\section{Frank Lamy}

Alfred Wegener Institute for Polar and Marine Research https://orcid.org/0000-0001-5952-1765

\section{Article}

\section{Keywords:}

Posted Date: January 11th, 2022

DOI: https://doi.org/10.21203/rs.3.rs-1199164/v1

License: (1) (1) This work is licensed under a Creative Commons Attribution 4.0 International License.

Read Full License

Version of Record: A version of this preprint was published at Nature Communications on November 11th, 2022. See the published version at https://doi.org/10.1038/s41467-022-33753-4. 


\section{Abstract}

Southern Ocean deep-water circulation plays an important role in the global carbon cycle. On geological time-scales, upwelling along the Chilean continental margin likely contributed to the deglacial atmospheric carbon dioxide rise, but little quantitative evidence exists of carbon storage. Here, we use a new X-ray Micro-Computer-Tomography method to assess foraminiferal test dissolution as proxy for paleo-carbonate ion concentrations $\left(\left[\mathrm{CO}_{3}{ }^{2-}\right]\right)$. Our subantarctic Southeast Pacific sediment core depth transect shows significant deep-water $\left[\mathrm{CO}_{3}{ }^{2-}\right]$ variations during the Last Glacial Maximum and Deglaciation (10 - $22 \mathrm{ka} \mathrm{BP})$. We provide evidence for an increase in $\left[\mathrm{CO}_{3}{ }^{2-}\right]$ during the early deglacial period (15-19 ka BP), followed by a ca. $40 \mu \mathrm{mol} \mathrm{kg}^{-1}$ reduction in Lower Circumpolar Deepwater (CDW). This decreased Pacific to Atlantic export of low-carbon CDW contributed to significantly lowered carbon storage within the Southern Ocean, highlighting the importance of a dynamic Pacific-Southern Ocean deep-water reconfiguration for shaping late-glacial oceanic carbon storage, and subsequent deglacial oceanic-atmospheric $\mathrm{CO}_{2}$ transfer.

\section{Introduction}

Antarctic ice core records provide unambiguous evidence that glacial $p \mathrm{CO}_{2}$ in the atmosphere was $\sim 80$ ppm lower than during the present and past interglacial periods ${ }^{1,2}$. Since the oceanic carbon pool is about 50 times larger than the atmosphere ${ }^{3,4}$, the deep ocean reservoir of dissolved inorganic carbon (DIC) and changes in the Meridional Overturning Circulation (MOC) likely played a pivotal role in modulations of $\mathrm{pCO}_{2}$. However, a consensus on the contributions of specific marine reservoirs for glacial carbon storage, their connections to major deep-water masses and their temporal and spatial variations in storage capacity has yet to emerge to better understand glacial-interglacial $p \mathrm{CO}_{2}$ change and atmosphere-ocean dynamics. Few places in the world ocean bear the potential like the Southern Ocean to directly connect the deep oceanic reservoir with the atmosphere via surface exchange processes, thus playing a key role in regulation of atmospheric $p \mathrm{CO}_{2}$ change.

Reconstructions by carbon isotope $\left(\delta^{13} \mathrm{C}\right)$ and $\mathrm{Cd} / \mathrm{Ca}$ from benthic foraminifera have indicated a weaker and shallower Atlantic $\mathrm{MOC}^{5,6}$, resulting in a deep ocean high in nutrients and carbon, which was more isolated from the atmosphere during the $\mathrm{LGM}^{7,8}$. The glacial deep Pacific and Southern Ocean, in particular, are considered to have been more stratified, and carbon-rich bathyal waters were thus more effectively sequestered and isolated from the atmosphere ${ }^{9-13}$. Both the year-round expansion of sea ice around Antarctica to the edge of the modern winter sea ice maximum ${ }^{14}$, and a northward shift of the Southern Westerly Wind Belt (SWW) are thought to be underlying forcing factors for this glacial pattern ${ }^{15,16}$. While direct evidence of carbon storage and release in this area is scarce, previous studies ${ }^{11-}$ 13, 17 showed that the deep Pacific below 2000 m water depth was generally less well ventilated during the glacial period, thereby conditioning such old deep-water in the Pacific and Southern Ocean to become a source of carbon efflux in the following deglaciation. 
Today, the subantarctic South Pacific water mass structure is characterized by the subduction of Antarctic Intermediate Water (AAIW) to water depths of about 500-1000 m and Antarctic Bottom Water (AABW) below $4500 \mathrm{~m}$, which moves northwards ${ }^{18}$. The water mass between $1000-4000 \mathrm{~m}$ depth is defined as Circumpolar Deep Water (CDW), which consists mainly of aged North Atlantic Deep Water (NADW), with smaller contributions of Pacific Deep Water (PDW) and AABW. The northward-flowing CDW ultimately turns back southward as PDW and is upwelled between AAIW and AABW in the polar South Pacific. Modern CDW is divided into Upper CDW (UCDW), relatively more influenced by PDW characteristics, and Lower CDW (LCDW), relatively more influenced by AABW characteristics. Two, nonexclusive distinct water masses are prime candidates for glacial carbon storage: $A A B W^{13,19,20}$, and PDW 21,22 , located in the upper bathyal (1500-3000 m) in the South Pacific.

For the geological past, most interpretations of changes in overturning circulation and water mass characteristics are based on measurements of $\delta^{13} \mathrm{C}$, radiocarbon ventilation ages or radiogenic isotope proxies $^{12.13}$, which do not directly provide information on quantitative changes in carbonate chemistry or DIC budgets. Because variations in deep-water carbonate ion concentration ([ $\left.\mathrm{CO}_{3}{ }^{2-}\right]$ ) are primarily governed by DIC and alkalinity, determination of quantitative $\left[\mathrm{CO}_{3}{ }^{2-}\right]$ is essential to define carbon storage in the deep ocean.

The $\mathrm{B} / \mathrm{Ca}$ ratio of epifaunal benthic foraminifera, particularly Cibicidoides wuellerstorfi, has so far been the deep-water $\left[\mathrm{CO}_{3}{ }^{2-}\right]$ proxy used mostly ${ }^{23}$, even though the relationship between $\mathrm{B} / \mathrm{Ca}$ and $\left[\mathrm{CO}_{3}{ }^{2-}\right]$ rests largely on empirical evidence and remains mechanistically unidentified. For the Pacific sector of the Southern Ocean, B/Ca data from the subpolar Southwest Pacific show a significant decrease in $\left[\mathrm{CO}_{3}{ }^{2-}\right]$ of $\sim 15 \mathrm{~mol} \mathrm{~kg}^{-1}$ at the boundary of AAIW and PDW during the LGM. This supposed higher glacial DIC storage was followed by a ca. $20 \mathrm{~mol} \mathrm{~kg}^{-1}$ increase during the early deglacial, indicating subsequent DIC release to the atmosphere ${ }^{24}$. However, because the $\mathrm{B} / \mathrm{Ca}$ method requires mono-specific epifaunal benthic foraminifera for measurements, which suitable Pacific and Southern Ocean locations are often lacking, $\left[\mathrm{CO}_{3}{ }^{2-}\right]$ reconstructions to date are restricted to a few sites shallower than UCDW ${ }^{24,25}$.

Deep-water carbonate saturation $\left(\Delta\left[\mathrm{CO}_{3}{ }^{2-}\right]\right)$ largely controls the dissolution of planktic foraminiferal tests, which are widely distributed in deep-sea sediment. Because $\Delta\left[\mathrm{CO}_{3}{ }^{2-}\right]$ is primarily governed by $\left[\mathrm{CO}_{3}{ }^{2-}\right]$ on glacial-interglacial time scales, measurements of planktic foraminiferal test dissolution intensity can provide information about past $\left[\mathrm{CO}_{3}{ }^{2-}\right]$. The size-normalized weight of planktic foraminiferal tests, particularly test area density $\left(\mu \mathrm{g} \mathrm{m}^{-2}\right)$, is a conventional proxy of carbonate dissolution intensity in under-saturated water ${ }^{26,27}$. However, because the size-normalized weight of planktic foraminifera is also controlled by surface water carbonate chemistry ${ }^{28,29}$, quantitative reconstructions of deep-water $\left[\mathrm{CO}_{3}{ }^{2-}\right.$ ] in the areas, where glacial-interglacial sea surface environmental variation was large, is difficult.

Here, we employ a new proxy approach to derive $\left[\mathrm{CO}_{3}{ }^{2-}\right]$ based on the dissolution of planktic foraminiferal tests of Globigerina bulloides (G. bulloides), using the test density analyzed by X-ray micro- 
CT scanning (XMCT). This new proxy overcomes weaknesses of conventional dissolution proxies ${ }^{30-32}$, while showing significant correlation with deep-water $\Delta\left[\mathrm{CO}_{3}{ }^{2-}\right]^{33}$. We apply this new method to reconstruct $\left[\mathrm{CO}_{3}{ }^{2-}\right]$ change in the subantarctic SE Pacific from the LGM across the deglaciation (10-21 ka BP). We studied a depth transect comprising four sediment cores collected off the southern Chilean margin and in the abyssal South Pacific, from water depths between 1500 and $4100 \mathrm{~m}$. These sites are located in a sensitive position to distinguish between Northern $v s$. Southern-sourced water mass contributions to the deep oceanic carbon pool, prior to their export into the Atlantic via the ACC through Drake Passage. Our $\left[\mathrm{CO}_{3}{ }^{2-}\right]$ reconstructions from these sediment cores enable us to assess the vertical distribution of dissolved inorganic carbon (DIC) in CDW and the influence from mixing with surrounding deep-water masses (PDW, AABW, and NADW) (Figure 1). Based on this depth transect reconstruction of $\left[\mathrm{CO}_{3}{ }^{2-}\right]$ in the SE Pacific, we suggest a dynamic, but transient, deglacial re-distribution of DIC after the LGM, along atmospheric $p \mathrm{CO}_{2}$ changes.

\section{Results}

\section{A new proxy method for $\left[\mathrm{CO}_{3}{ }^{2-}\right]$ applied to the SE Pacific}

A new dissolution index (\%Low-CT-number calcite volume) obtained from XMCT scanning, enables us to measure the planktic foraminiferal test density of G. bulloides excluding the effect of wall thickness, and provides a reliable method to evaluate the dissolution intensity of tests.

The internal structure of $G$. bulloides tests shows selective dissolution of inner calcite, and CT number histograms changed from mono-modal to bi-modal distribution with the progress of dissolution (Figure 2a), indicating that relative volume of low CT number calcite increases with dissolution, confirming earlier studies $^{31,32}$. Calibration between dissolution IDX (\%Low-CT-number calcite volume) and deep-water $\Delta\left[\mathrm{CO}_{3}{ }^{2-}\right]$ at each core site shows that the \% Low-CT-number calcite volume serves as a quantitative proxy of deep-water $\Delta\left[\mathrm{CO}_{3}{ }^{2-}\right]$ (Figure $2 \mathrm{~b}$ ). Our regression equation is as follows:

(1) $\Delta\left[\mathrm{CO}_{3}{ }^{2-}\right]=-1.45 \times(\%$ Low-CT-number calcite volume $)+46.3, \mathrm{R}^{2}=0.91$

Assuming constant $\left[\mathrm{Ca}^{2+}\right]$ on a time scale shorter than $100 \mathrm{ka}^{34}$, deep-water $\Delta\left[\mathrm{CO}_{3}{ }^{2-}\right]$ is controlled by $\left[\mathrm{CO}_{3}{ }^{2-}\right]$. Based on this equation $\left[\mathrm{CO}_{3}{ }^{2-}\right]$ at each core site was calculated using the following equation under the assumption of stable temperature and salinity of deep-water after the last glacial period:

(2) $\left[\mathrm{CO}_{3}{ }^{2-}\right]=-1.45 \times(\%$ Low-CT-number calcite volume $)+\mathrm{a}$

The $\mathrm{a}$ is a constant depending on the sediment core water depth, bottom water temperature and salinity at each core site. Based on the regression between in-situ deep-water $\Delta\left[\mathrm{CO}_{3}{ }^{2-}\right]$ and the \%Low-CT-number 
calcite volume, the uncertainty associated with reconstructing deep-water $\Delta\left[\mathrm{CO}_{3}{ }^{2-}\right]$ is $3.4 \mu \mathrm{mol} \mathrm{kg}{ }^{-1}$, which makes it possible to detect $\sim 10 \mu \mathrm{mol} \mathrm{kg}{ }^{-1}$ variations of $\left[\mathrm{CO}_{3}{ }^{2-}\right]$ on the millennial time-scales.

\section{Deglacial $\left[\mathrm{CO}_{3}{ }^{2-}\right]$ reconstruction: evolution of deep SE Pacific carbonate chemistry}

Among four sediment cores, water depths in the SE Pacific with water depths ranging from ca. 1500 to $4100 \mathrm{~m}$ (Figure 3a-d) with our first shallowest mesopelagic site PC01 ( $\left.46^{\circ} 04 \mathrm{~S}, 75^{\circ} 41 \mathrm{~W}, 1535 \mathrm{~m}\right)$, bathed in UCDW and AAIW, yields low $\left[\mathrm{CO}_{3}{ }^{2-}\right.$ ] values of 65 to $73 \mu \mathrm{mol} \mathrm{kg}{ }^{-1}$ during the early deglaciation (15-19 ka BP). Thereafter, site PC01 values decrease to around $60 \mu \mathrm{mol} \mathrm{kg}{ }^{-1}$ at the end of the Younger Dryas (11.5 ka BP) (Figure 3a). Our second, slightly deeper upper bathyal site PC02 (46 $04 \mathrm{~S}, 76^{\circ} 32 \mathrm{~W}, 2793 \mathrm{~m}$ ) is also bathed in UCDW, but under a more pronounced influence of aged NADW. During the LGM (19-21 ka BP), PC02 shows values between $77-90 \mu \mathrm{mol} \mathrm{kg}^{-1}$, followed by a short, foraminifera-barren interval, supposedly driven by a carbonate dissolution event due to low $\left[\mathrm{CO}_{3}{ }^{2-}\right]$ deep water intrusion at the end of the LGM (19-19.5 ka BP). Thereafter, the $\left[\mathrm{CO}_{3}{ }^{2-}\right]$ in PCO2 increased to values of around $85 \mu \mathrm{mol} \mathrm{kg}^{-1}$ during the early deglaciation (17-19 ka BP), followed by a significant decrease to $67 \mu \mathrm{mol} \mathrm{kg}{ }^{-1}$ towards end around $15 \mathrm{ka} \mathrm{BP}$ ) (Figure 3). Our third, lower bathyal site PC03 ( $46^{\circ} 24 \mathrm{~S}, 77^{\circ} 19 \mathrm{~W}, 3072 \mathrm{~m}$ ) is bathed in LCDW with influence of AABW. Notably, this site shows mostly similar variations as PCO2 during the LGM (19-21 ka BP), albeit with lower values around $75 \mu \mathrm{mol} \mathrm{kg}{ }^{-1}$ at the end of the LGM around $19 \mathrm{ka}$ BP. Thereafter, values in both cores start to diverge during the early deglaciation (15 - $19 \mathrm{ka} \mathrm{BP}$ ), with significant $\left[\mathrm{CO}_{3}{ }^{2-}\right]$ increases from 75 to $95 \mu \mathrm{mol} \mathrm{kg}{ }^{-1}$ at the deeper site PC03 (Figure 3c). Our deepest, abyssal site PS75/054-1 (56 ${ }^{\circ} \mathrm{S}, 115^{\circ} \mathrm{W}, 4085 \mathrm{~m}$ ), is bathed in LCDW and admixture of AABW from below. In contrast to our three shallower sites, this latter record shows a continuous decrease from relatively high glacial values of 100 to Early Holocene values of ca. $84 \mu \mathrm{mol} \mathrm{kg}^{-1}$ (Figure 3d).

A short-term, but distinct carbonate preservation event lasting from $18-18.4$ ka BP is evident in our bathyal cores PC02 and PC03. During this time interval, a significant maximum in sediment deposition occurs, as evidenced by an age model-based 50-100-fold sedimentation rate increase to ca. $200 \mathrm{~cm} \mathrm{ka}^{-1}$. which likewise, XRF-scanning-derived $\mathrm{Ti} / \mathrm{K}$ ratios yield simultaneous maxima, be caused by suggesting higher input of terrestrial materials from the volcanic area of the Andes Cordillera ${ }^{35}$, while $\mathrm{Zr} / \mathrm{Rb}$ ratio increases indicate stronger bottom current flow ${ }^{36}$ (Figure $3 \mathrm{f}$ ). We thus assume that a transient highsedimentation event of terrestrial material likely promoted carbonate preservation at the seafloor ${ }^{37,38}$, with foraminiferal test dissolution being in temporary disequilibrium with ambient deep-water, while it was the fact that the amount of carbonate dissolution at deep sea floor have clearly decline during this period. Therefore, we consider that reconstructed $\left[\mathrm{CO}_{3}{ }^{2-}\right]$ values during this short 400 -year period between 18 and $18.4 \mathrm{ka}$ BP are unreliable, and thus do not consider these data points in the following discussion.

\section{Factors influencing $\left[\mathrm{CO}_{3}{ }^{2-}\right]$ changes: potential effects of export production and vertical mixing}


Biological productivity in the surface ocean and organic matter remineralization below is one of the potential factors that alters deep water $\left[\mathrm{CO}_{3}{ }^{2-}\right]$. In the Southern Ocean, surface ocean biological

productivity is considered to have been generally low in the LGM and high in the early deglaciation ${ }^{39}$. At a nearby upper Chilean margin, variations in the $\mathrm{Br} / \mathrm{Ca}$ ratio as an indication of biological carbon pump efficiency in this area, were used to suggest a more efficient biological carbon pump at the end of LGM (19 ka BP), combined with lower efficiency during the early deglaciation (15-19 ka BP $)^{40}$. In our study, however, the $\mathrm{Br} / \mathrm{Ca}$ ratio at deeper bathyal sites $\mathrm{PC0} 2$ and $\mathrm{PC0} 3$ (Figure $3 \mathrm{e}$ ) are generally higher during the early deglaciation (15-19 ka BP) than at the end of LGM (19 ka BP). This differing result is likely caused by local differences in surface productivity and/or depth-dependent differences in the carbonate preservation at our bathyal PC02 and PC03 sites, which indicates that organic carbon was effectively buried in sediment during the early deglaciation (15-19 ka BP) (Figure 3e). Considering that carbonate was relatively better preserved during the early deglaciation (15-19 ka BP) than the LGM (19 ka BP), we suppose that the biological productivity at sea surface is not a principal controlling factor of deep water $\left[\mathrm{CO}_{3}{ }^{2-}\right]$ variation at our study sites.

On the other hand, variations in the geochemical characteristics of deep-water masses are an alternative factor that potentially alters deep water $\left[\mathrm{CO}_{3}{ }^{2-}\right]$. In previous studies, ventilation age reconstruction (i.e., ${ }^{14} \mathrm{C}$ age difference between planktic and benthic foraminifera) suggested that South Pacific deep-water mass were less ventilated and more isolated from the atmosphere, in line with a presumed strong stratification, during the LGM (19 ka BP), followed by enhanced mixing with well-ventilated surface water during the early deglaciation (15-19 ka BP $)^{11,12}$. In addition, radiogenic isotope results, which indicate the contribution from AABW supplied from the Ross Sea, suggested the breakup of deep bathyal water stratification after the LGM and enhanced mixing of AABW into shallower water masses ${ }^{13}$. In our study, the results of difference in stable carbon isotope of planktic and benthic foraminifera $\left(\Delta \delta^{13} \mathrm{C}\right.$ planktic benthic) in bathyal PC03, which imply the strength of bottom-surface ventilation ${ }^{11}$, suggests the stratification at the LGM (19 ka BP), followed by enhanced ventilation at the end of early deglaciation (15 ka BP) (Figure 3g). Furthermore, the results of $\mathrm{Zr} / \mathrm{Rb}$ ratios in bathyal sites (PC02 and PC03), which cab bu used to trace variations in current strength in ocean bottom currents ${ }^{36}$, suggests an increase at the end of early deglaciation (15-16.5 ka BP) (Figure 3f). These results are consistent with previous interpretations that South Pacific deep-water masses were well-stratified and isolated from the atmosphere during the LGM, followed by maximum mixing and ventilation at the end of early deglaciation (15 ka BP). Therefore, we consider the carbonate chemical condition in deep-water mass to be principally governed by the chemical dynamics of deep-water mass structure in our area.

\section{Transient zonal and meridional dynamics of Pacific deep-water carbonate chemistry}

Deep-water mass biogeochemical configurations contribute to changes in vertical $\left[\mathrm{CO}_{3}{ }^{2-}\right]$ profiles in two ways. One is the variation in deep-water structures due to change in deep-water circulation, and the other one is changes of DIC within each water mass due to release and uptake of atmospheric $\mathrm{CO}_{2}$. However, 
these factors interact with each other, and change in deep-water mass structures can be interpreted as changes in carbon storage at a specific water depth and area. In this study, we found significant postLGM variations of 65 to $90 \mu \mathrm{mol} \mathrm{kg}{ }^{-1}$ in the $\left[\mathrm{CO}_{3}{ }^{2-}\right]$ at bathyal sites PC02 and PC03. These variations fluctuate between the $\left[\mathrm{CO}_{3}{ }^{2-}\right]$ of the mesopelagic site PC01 and abyssal site PS75/054-1 (Figure 4b), implying that the deep-water masses at bathyal sites around the depth of 2000-3000 m are principally a mixing product of the surrounding water masses.

Among our four sediment cores, site PC01 is strongly influenced by upper water masses originating from the north. A previous ventilation age reconstruction on a core close to site PC01 (MD07-3088) suggested a strong stratification and effect of PDW at the end of LGM (19 ka BP), followed by enhanced vertical mixing and increasing influence of well-ventilated deep waters during the early deglacial (Figure 4d) ${ }^{11}$. Upstream of our core sites, the $\left[\mathrm{CO}_{3}{ }^{2-}\right]$ of PDW was reconstructed in the Equatorial East Pacific at Site ODP1240 (2921 m: shown in Figure 4b), using B/Ca of benthic foraminifera, suggesting aged, low [ $\mathrm{CO}_{3}{ }^{2-}$ ] PDW during the $\mathrm{LGM}^{22}$. On the other hand, our deepest, abyssal site PS75/054-1, reflecting AABW supplied from the Ross Sea remains largely invariant in its $\left[\mathrm{CO}_{3}{ }^{2-}\right]$, despite previous suggestions of increased mixing with bathyal water masses from above during the early deglaciation based on $\varepsilon \mathrm{Nd}$ analyses ${ }^{13}$. Therefore, we assume that the $\left[\mathrm{CO}_{3}{ }^{2-}\right]$ of $\mathrm{CDW}$ as recorded in our bathyal sites PC02 and

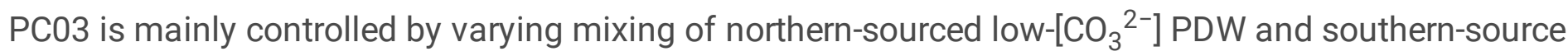
higher-[$\left[\mathrm{CO}_{3}{ }^{2-}\right] \mathrm{AABW}$.

During the $\mathrm{LGM}$, our bathyal $\left[\mathrm{CO}_{3}{ }^{2-}\right.$ ] reconstructions from sites PC02 and PC03 significantly differ from values at shallower and deeper sites PC01 and PS75/054-1, respectively. Considering that the South Pacific deep-water mass structure was supposedly strongly stratified and isolated from the atmosphere during this period (Figure 4d, e) ${ }^{11,13}$, glacial CDW was likely less influenced by water masses supplied from north and south. Some proxy reconstructions suggest that the AMOC was relatively strong (Figure 5c) during the $\mathrm{LGM}^{41,42}$, and therefore, glacial CDW should have been affected by deep-water supply from NADW. In fact, reconstructions from the subantarctic Southern Atlantic revealed that the $\left[\mathrm{CO}_{3}{ }^{2-}\right]$ of NADW at the depth of ca. $3800 \mathrm{~m}$ was around $70 \mu \mathrm{mol} \mathrm{kg}^{-1}$ during the $\mathrm{LGM}^{43}$, similar to CDW measured here. During the early deglacial (15-19 ka BP), the AMOC was weakened (Figure $5 \mathrm{c}$ ), with suppressed NADW supply. Furthermore, deep-water stratification in the Southern Pacific was gradually breaking up ${ }^{11-13}$ (Figure 4d, e), and CDW became variably controlled by both, inflow of northern-sourced shallower, and southern-sourced deeper water masses.

In the following, we discuss the varying contributions of surrounding water masses to CDW during the deglaciation (15 -19 ka BP). Firstly, at the beginning of the early deglaciation (17-19 ka BP), the bathyal $\left[\mathrm{CO}_{3}{ }^{2-}\right]$ in both PC02 and PC03 temporally increased to $85 \mu \mathrm{mol} \mathrm{kg}{ }^{-1}$, converging to similar values with that of abyssal site PS75/054-1, suggesting that CDW was temporally homogenized with a more pronounced AABW. At that time, SE Pacific deep-water masses were still isolated from the atmosphere, as 
evidenced by ventilation age reconstruction in nearby core MD07-3088 and $\Delta \delta^{13} \mathrm{C}$ (planktic -benthic foraminifera) in PC03 (Figure 3g). Thereafter, the $\left[\mathrm{CO}_{3}{ }^{2-}\right]$ in our bathyal sites PC02 and PC03 gradually diverged, with the shallower core PC02 converging to northern-sourced PDW signatures towards the end of early deglaciation (15 ka BP). This implies that the influence of northern-sourced PDW gradually increased, and reached a maximum expansion at the end of early deglaciation (15 ka BP).

Our quantitative reconstruction of SE Pacific deep-water $\left[\mathrm{CO}_{3}{ }^{2-}\right]$ enables us to compare our location to other key regions and to assess potential connections and spatial distributions of deep-water carbon storage. As a first step, we compare the variations in deep-water carbon storage based on deep-water $\left[\mathrm{CO}_{3}{ }^{2-}\right]$ between the SW Pacific ${ }^{24,25}$ and the SE Pacific (this study). Under modern conditions, the main flow of abyssal AABW to the north is located in the SW Pacific in the Deep Western Boundary Current system. In contrast, the return flow of DIC-rich and low- $\left[\mathrm{CO}_{3}{ }^{2-}\right]$ PDW is mostly located in the SE Pacific basins at bathyal depths of $2000-3500 \mathrm{~m}^{44}$. In the subantarctic SW Pacific, the variations in $\left[\mathrm{CO}_{3}{ }^{2-}\right]$ were recently reconstructed along a depth transect of three sites from $1160 \mathrm{~m}, 1630 \mathrm{~m}$ and $2540 \mathrm{~m}$ located off New Zealand, using B/Ca ratios of benthic foraminifera ${ }^{24,25}$ (Figure 4c). In particular, the mesopelagic SW Pacific showed low and stable $\left[\mathrm{CO}_{3}{ }^{2-}\right]$ values of around $60 \mu \mathrm{mol} \mathrm{kg}{ }^{-1}$ at the beginning of the early deglaciation (17-19 ka BP), followed by a mid-deglacial $15-20 \mu \mathrm{mol} \mathrm{kg}^{-1}$ increase beginning around 17 ka BP. These results provide evidence for a reduction in deep-water carbon storage accompanied by strengthened vertical mixing at the end of the early deglaciation ${ }^{12}$. Compared to our vertical profile of $\left[\mathrm{CO}_{3}{ }^{2-}\right]$ in the SE Pacific that without $\left[\mathrm{CO}_{3}{ }^{2-}\right]$ increase in mesopelagic and upper bathyal sites, this suggests that a reduction in deep-water carbon storage occurred in shallower depths in the SW than in the SE Pacific (Figure 4). This asymmetrical east-west imbalance in Southern Pacific carbon storage was most likely caused by the preferential low-[ $\left.\mathrm{CO}_{3}{ }^{2-}\right]$ PDW import from the north into the SE Pacific. Thus, spatial reconstructions of deep-water masses and their biogeochemical signatures in both meridional (north-south) and zonal (east-west) directions are indispensable for a quantitative and process-oriented understanding of variations in marine carbon storage and its transfer between different reservoirs.

\section{Pacific-Atlantic deep-water export through ACC transport: Implications for the Southern Ocean carbon budget}

In order to elucidate the mechanisms causing pre-anthropogenic atmospheric $\mathrm{CO}_{2}$ variations and marine atmospheric carbon transfer, one has to understand the inter-basin transport within the global MOC through the Southern Ocean as central intersection. In fact, it was suggested that glacial PDW, supplied into the Atlantic Ocean via Drake Passage, played a positive feedback role in increased carbon storage in the South Atlantic during the $\mathrm{LGM}^{43}$. However, data of previous deep-water $\left[\mathrm{CO}_{3}{ }^{2-}\right]$ reconstructions are limited to the SW and equatorial Pacific $22,24,25$, both distal to the Drake Passage as entrance to the Atlantic Ocean. Hence, our cores from the SE Pacific Chilean margin, close to the Drake Passage, enable us to better assess the transport and carbonate chemistry of deep-water masses exchanged between the Pacific and Atlantic. The intensity of Drake Passage throughflow is governed by the Antarctic 
Circumpolar Current (ACC), and past changes in throughflow over the last glacial have been reconstructed by grain size and geochemical analyses ${ }^{36,45,46}$. These results suggest that the Drake Passage throughflow was weaker during the LGM, and gradually strengthening in the termination, with a maximum at the end of early deglaciation (Figure $5 \mathrm{~d}$ ). In the South Atlantic, variations in $\left[\mathrm{CO}_{3}{ }^{2-}\right.$ ] of $\mathrm{CDW}$ and $A A B W$ were reconstructed with $B / C$ a ratios of benthic foraminifera ${ }^{43}$, showing different values between $C D W$ and $A A B W$ during the LGM and early deglaciation (16.5-19 $\mathrm{ka} \mathrm{BP}$ ), while the $\left[\mathrm{CO}_{3}{ }^{2-}\right]$ of CDW increased after $16.5 \mathrm{ka}$ and showed similar values as AABW at $15 \mathrm{ka}$ BP (Figure 5b). Based on our deep-water $\left[\mathrm{CO}_{3}{ }^{2-}\right]$ reconstruction, we estimated the DIC variations at each site in the SE Pacific Chilean margin, using modern bottom water parameters (Total Alkalinity, Temperature and Salinity) as boundary conditions (Figure 5a). These estimates indicate a temporal change in the Southern Ocean's deep-water structure, with a more pronounced influence of higher deep-water transport from the Pacific to the Atlantic on the carbon cycle after the LGM. (Figure 6)

During the LGM (Figure 6a), Southern Ocean surface biological productivity is thought to have been generally low due to high surface stratification ${ }^{39}$. However, data from the Chilean margin suggest that the biological carbon pump was relatively stronger during the LGM than the deglaciation, due to lowered carbonate production ${ }^{40}$, which contributed to effective carbon uptake from the atmosphere. The deep Southern Ocean is considered to have been well-stratified ${ }^{12,13}$, and therefore, Pacific CDW was more isolated from the surrounding water masses, ultimately leading to DIC-rich, aged PDW flowing eastward through the Drake Passage. The DIC estimate implies that carbon storage was larger in bathyal Pacific CDW than in AABW (Figure 5a), and therefore, Atlantic southern-sourced deep-waters were likely affected by such carbon-rich PDW-influenced CDW export from the SE Pacific via Drake Passage.

At the beginning of the early deglaciation (17-19 ka BP), our results in SE Pacific suggest expansion and mixing of $A A B W$ into overlying $\mathrm{CDW}$, shown by homogenous $\left[\mathrm{CO}_{3}{ }^{2-}\right]$ in Pacific $\mathrm{CDW}$. At the same time, deep-water $\left[\mathrm{CO}_{3}{ }^{2-}\right]$ reconstructions in Atlantic $\mathrm{CDW}$ and $\mathrm{AABW}$ yield diverging values ${ }^{43}$, suggesting that low $\left[\mathrm{CO}_{3}{ }^{2-}\right]$ Atlantic CDW was relatively isolated from Atlantic AABW. Deep-water in the SE Pacific was still strongly stratified and carbon discharge to the atmosphere hence suppressed, implying that the $\left[\mathrm{CO}_{3}{ }^{2-}\right]$ of deep-water remained low. In addition, deep-water export from the Pacific to the Atlantic through Drake Passage was strengthened gradually, enabling a leakage of low $\left[\mathrm{CO}_{3}{ }^{2-}\right]$, carbon-rich Pacific UCDW, contributing to the low Atlantic $\mathrm{CDW}\left[\mathrm{CO}_{3}{ }^{2-}\right]$ values $\left(70 \mu \mathrm{mol} \mathrm{kg}{ }^{-1}\right)$. Thereafter, at the end of the early deglaciation (15-16.5 ka BP) (Figure 6b), deep-water $\left[\mathrm{CO}_{3}{ }^{2-}\right]$ in Atlantic CDW increased and showed values similar to AABW $\left(90 \mu \mathrm{mol} \mathrm{kg}{ }^{-1}\right)$. This seems to have been caused by enhanced transport of Pacific LCDW into the South Atlantic, due to strengthened Drake Passage flow. In addition, re-juvenated carbon-poor waters originating from upwelled northern-sourced PDW were transported into Atlantic CDW. At this period, the DIC estimate of Pacific LCDW decreases (Figure 4a), suggesting that better ventilated, low DIC deep-water was exported to the Atlantic and mixed into Atlantic LCDW and AABW (Figure 6b). 
Our quantitative reconstruction of deep-water $\left[\mathrm{CO}_{3}{ }^{2-}\right]$ based on the depth transect in the SE Pacific, a central junction point connecting the Pacific and the Atlantic Ocean, suggests that dynamic, transient variations in deep-water structure and carbon chemistry characteristics largely shape and determine the amount of carbon stored in the Southern Ocean. In particular, the volumetric expansion of Pacific CDW with high $\left[\mathrm{CO}_{3}{ }^{2-}\right.$, caused by the deglacial reconfiguration of abyssal to bathyal waters in the Southern Ocean likely contributed to the reduction of the carbon storage in CDW, and was followed by effective carbon discharge due to enhanced surface ocean ventilation of deep-water masses.

Our $\left[\mathrm{CO}_{3}{ }^{2-}\right]$ reconstruction also enables us to roughly estimate changes in the bathyal to abyssal carbon budget. During the LGM to early deglaciation (15-19 ka BP), atmospheric $p \mathrm{CO}_{2}$ increased from 180 to 210 ppm, which corresponds to carbon efflux of approximately $63 \mathrm{GtC}$ to the atmosphere. The $\left[\mathrm{CO}_{3}{ }^{2-}\right]$ reconstructions for our bathyal site PC03 show a ca. $20 \pm 9 \mu \mathrm{mol} \mathrm{kg}{ }^{-1}$ increase in the SE Pacific, which corresponds to a $40 \pm 15 \mu \mathrm{mol} \mathrm{kg}{ }^{-1}$ reduction in DIC under the assumption that bottom water parameters (Total Alkalinity, Temperature and Salinity) were stable, analog to the modern condition. If deep-water DIC of LCDW in the South Pacific (assumption of water mass distribution range: $40^{\circ} \mathrm{S}-70^{\circ} \mathrm{S}, 135^{\circ} \mathrm{W}-150^{\circ} \mathrm{W}$, 3000-4000 m water depth) was uniformly reduced by $40 \mu \mathrm{mol} \mathrm{kg}^{-1}$, the amount of carbon efflux from this water mass can be estimated as ca.12 GtC. This corresponds to $19 \pm 7 \%$ of the total carbon emission to the atmosphere during this period. This estimate is based on the assumption that deep-water parameters are stable after the LGM to modern. In fact, however, ocean alkalinity varies on glacial-interglacial time scale, and deep-water alkalinity is generally higher in glacials than interglacials ${ }^{45}$. Previous proxy studies suggested that deep Southern Ocean alkalinity was $\sim 25 \mu$ molkg$^{-1}$ higher in glacials than in interglacials ${ }^{46}$. In addition, box model studies estimated higher alkalinity values of $\sim 300 \mu \mathrm{mol} \mathrm{kg}^{-1}$ in the deep Southern Ocean during glacial periods ${ }^{47}$. Assuming glacial alkalinity of the deep ocean was higher than under modern conditions, deep-water DIC would also be also higher than under the assumption of stable alkalinity, suggesting that the amount of carbon efflux from Pacific LCDW after the LGM is likely higher than $12 \mathrm{GtC}$. Therefore, our results imply that the amount of carbon corresponds to $19 \%$ or more of the total amount of carbon discharge from ocean to atmosphere during the early deglaciation, was emitted from Pacific LCDW during this period. Lastly, we suggest that carbon storage in South Pacific LCDW played an indispensable role in the atmospheric $p \mathrm{CO}_{2}$ rise during the early deglaciation.

\section{Material And Methods}

\section{Core Sampling}

Three piston cores were sampled during cruise MR16-09_leg.2 of R/V Mirai (Jan. 20-Feb. 5) conducted by the Japan Agency for Marine-Earth Science and Technology (JAMSTEC) in 2017. In addition, we used piston core PS75/054-1 retrieved during cruise PS 75 of R/V Polarstern. Core sites were located on the slope of Chile margin between $1535 \mathrm{~m}$ to $3072 \mathrm{~m}$ (PC01: $46^{\circ} 04 \mathrm{~S}, 75^{\circ} 41 \mathrm{~W}, 1535 \mathrm{~m}$; PC02: $46^{\circ} 04 \mathrm{~S}, 76^{\circ} 32$ W, $2793 \mathrm{~m} ; \mathrm{PC} 03: 46^{\circ} 24 \mathrm{~S}, 77^{\circ} 19 \mathrm{~W}, 3072 \mathrm{~m}$ ) and in the abyssal Southeast Pacific sector of the Southern 
Ocean (PS75/054-1: $56^{\circ} \mathrm{S}, 115^{\circ} \mathrm{W}, 4085 \mathrm{~m}$ ) (Figure 1). The recovered sediment cores of PC01 and PC02 consist mainly of olive gray silty clay with intercalations of silty layers, and PC03 consists mainly of gray clay with intercalations of silty/sandy layers. Sediment cores were continuously sliced every $2.2 \mathrm{~cm}$ interval throughout the core. For the analysis of planktic foraminiferal test dissolution, we used 13 samples from upper $5.31 \mathrm{~m}$ of PC01, 16 samples from the upper $4.32 \mathrm{~m}$ of PC02 and 14 samples from the upper $2.58 \mathrm{~m}$ of PC03, respectively. From the core of PS75/054-1, 10 samples were chosen every 20 $\mathrm{cm}$ depth in core. From each sediment samples, eight unblemished tests of planktic foraminifera ( $G$. bulloides) were hand-picked from the 250-355 $\mu \mathrm{m}$ size fraction, and test dissolution intensities were measured by XMCT scanning.

Planktic foraminiferal test in the deep-sea floor sediment samples were obtained from the core tops (0-1 $\mathrm{cm}$ ) of Multiple Cores. Three Multi Cores and one Pilot Core were collected during cruise MR16-09_leg.2, and four Multiple Cores were collected during cruise PS97 of R/V Polarstern in 2016. The water depths of core sites were ranging from $1537-3851 \mathrm{~m}$, and deep-water $\Delta\left[\mathrm{CO}_{3}{ }^{2-}\right]$ at core sites ranged from -16.11 to $9.46 \mu \mathrm{mol} \mathrm{kg}{ }^{-1}$, calculated by using data from bottle sampling analysis during cruise MR16-09_leg.2 and nearby Global Ocean Data Analysis Project (GLODAP) sites ${ }^{50}$ (Table 1). 16-32 hand-picked tests of $G$. bulloides from each core top sample (250-355 $\mu \mathrm{m}$ size fraction) were selected for measurements of the mean area density $\left(\mu \mathrm{g} \mathrm{m}^{-2}\right)$ of the tests, and they were scanned by XMCT.

\section{Age model}

The age model for MR16-09 PC01 (whole core) were correlated to a giant piston core MD07-3088 from the same location with $\mathrm{PC} 01^{9}$ using Ca relative concentration records based on high-resolution XRF core scanning (Supplemental figure 3a, Age model). The age model of MD07-3088 was published previously and is based on the identification of five tephra layers and $24 \mathrm{AMS}{ }^{14} \mathrm{C}$-ages of planktic foraminifera $G$. bulloides. Based on the lithostratigraphic correlations, the age model of MD07-3088 was transferred to the age models of PC01. The age model for PC02 (upper $394 \mathrm{~cm}$ core depth) is based on the $12 \mathrm{AMS}{ }^{14} \mathrm{C}$ ages of planktic foraminifera (mixed), and this age model was transferred to the age model of PCO3 (upper $230 \mathrm{~cm}$ core depth) based on the peak matching of $\mathrm{Zr} / \mathrm{Rb}$ ratio records (Supplemental figure 3b, Age model). The age model of PCO3 is also supported by 3 AMS ${ }^{14} \mathrm{C}$-ages of planktic foraminifera. The measurements of AMS ${ }^{14} \mathrm{C}$-ages of PC02 was performed at the University Museum, the University Tokyo in Tokyo, Japan. Planktic ${ }^{14} \mathrm{C}$ ages were calibrated to calendar ages, using the calibration software Calib 8.20 with the MARINE20 calibration curve. All ages were all calibrated collected using reservoir ages from previous study ${ }^{11}$. For core PS75/054-1, we used the published age model ${ }^{13}$.

Based on the reconstructed age model, we found the significantly high sedimentation rate layer in PC02 (Depth in core: 200-400 cm) and PC03 (Depth in core: 100-200 cm) at 18.0-18.4 ka BP, which might be caused by input of allochthonous sediment due to turbidite deposite, or local sediment movement and redeposition (49. McCave et al., 1995).

\section{X-ray micro CT scanning}


The XMCT system (ScanXmate-D160TSS105/11000, Comscantecno Co., Ltd., Kanagawa, Japan) at the Japan Agency for Marine-Earth Science and Technology, Yokosuka, Japan, was used. For 3-D observation of the foraminiferal tests, we used a high-resolution setting (X-ray focus spot diameter, $0.8 \mu \mathrm{m}$; X-ray tube voltage, $80 \mathrm{kV}$; detector array size, $2000 \times 1336 ; 1500$ projections $/ 360^{\circ} ; 0.5 \mathrm{~s} /$ projection). After XMCT scanning, ConeCTexpress software (Comscantecno Co., Ltd.) was used to correct and reconstruct the tomography data. Image cross sections were reconstructed from filtered back projections following the general principle of Feldkamp cone beam reconstruction. The scanning and data processing methods were those of previous study ${ }^{31}$. The CT number, indicating calcite density, was calculated based on the Xray attenuation coefficient of each sample. In this study, a calcite standard crystal (a particle of NBS-19) was used to standardize the CT number of each test sample: the mean CT number of air and standard crystal were defined to be 0 and 1000, respectively, and the CT numbers of foraminiferal test samples were calculated according to the following equations:

(1) CT number $=\left(\mu_{\text {sample }}-\mu_{\text {air }}\right) /\left(\mu_{\text {calcite STD }}-\mu_{\text {air }}\right) \times 1000$

where $\mu_{\text {sample, }} \mu_{\text {calcite STD }}$, and $\mu_{\text {air }}$ are the X-ray attenuation coefficients of the sample, calcite standard crystal, and air, respectively.

We used Molcer Plus 3-D imaging software (WhiteRabbit Corp., Tokyo, Japan) to obtain isosurface images and to measure mean CT numbers and CT number histograms of foraminiferal tests based on the 3-D tomography data. The mass of voxels with a size of $0.8 \mu \mathrm{m}$, which have a specific CT number, was calculated on the basis of isosurface images of foraminiferal tests. The volumes of foraminiferal tests were calculated based on the total numbers of voxels in each scanned test. We also measured the test wall thickness of outermost chamber (final four chambers) of G. bulloides using iso-surface image, and the average of the outermost chamber wall thickness is shown as the mean wall thickness.

\section{Test dissolution Index}

For estimation of carbonate dissolution intensities, we employed variations of CT number histograms obtained by XMCT scanning. The pervious study ${ }^{31}$ have found that CT number histograms of dissolved G. bulloides test show bimodality of the dissolved and preserved calcite. Based on this result, they proposed the relative volume of low-CT-number calcite to the volume of calcite in the whole shell (\%LowCT-number calcite volume) as a more quantitative carbonate dissolution proxy for dissolution than the conventional test weight proxy. Based on this concept, we calculated \%Low-CT-number calcite volume to measure the dissolution intensity of $G$. bulloides tests using the following equations:

(4) \%Low-CT-number calcite volume $=\left(\mathrm{V}_{\text {low-CT-number calcite }} / \mathrm{V}_{\text {whole shell }}\right) \times 100$

where $\mathrm{V}_{\text {low-CT-number calcite }}$ indicates the volume of low-CT-number calcite in an individual test, and $\mathrm{V}_{\text {whole }}$ shell indicates the volume of the whole individual test. In this study, based on the results of XMCT scanning, we classified low CT-number and high CT-number calcite as calcite with CT number values of $200-500$ and $>500$, respectively. 


\section{Test area density measurement}

The mean area density of planktic foraminiferal test has been considered as a proxy for test dissolution intensity in the sediment samples bellow the lysocline. The mean weights $(\mu \mathrm{g})$ of $16 \mathrm{G}$. bulloides tests picked from sea floor sediment samples, size range from 250-355 $\mu \mathrm{m}$, were measured with an ultramicrobalance (Cahn C-35, Thermo Electron Corp., Round Rock, TX, USA). The analytical precision of the weight measurement was $\pm 0.3 \mu \mathrm{g}( \pm 1 \sigma)$ based on 15 repeated measurements. After the measurements of shell weights, 2-D projected areas $\left(\mu \mathrm{m}^{2}\right)$ of individual tests were measured with image analysis software (Motic Image Plus 2.1S, Shimadzu Rika Corp., Tokyo, Japan). The mean area density of $G$. bulloides tests were calculated using the following equation based on a previous study 29,52 .

(4) Mean area density $\left(\mu \mathrm{g} / \mu \mathrm{m}^{2}\right)=$ mean test weight $(\mu \mathrm{g}) /$ mean projected area $\left(\mu \mathrm{m}^{2}\right)$

Based on the analyses of planktic foraminiferal tests from undisturbed sediment surface samples, the mean area densities of $G$. bulloides tests show a positive correlation with the mean wall thickness of the outermost chamber (Supplement Figure 1a), indicating that the conventional proxy of mean area density is governed by test wall thickness in this study area. Furthermore, the geographical distribution of test area density differs with latitude, showing low area densities (thin test wall) in lower latitudes and high area densities (thick test wall) in higher latitudes (Supplement Figure 1b). Although it remains unsure which water parameters cause area density changes, the observed correlations between test area density, test wall thickness and collected latitude indicates that sea surface conditions alter the thickness of $G$. bulloides test wall, which control the test weight measurement of $G$. bulloides, suggesting that the conventional proxy of test area density based on the bulk test weight is unavailable for quantitative reconstruction of deep-water $\left[\mathrm{CO}_{3}{ }^{2-}\right]$ (Supplement Figure 1c).

\section{Stable isotope}

Stable oxygen and carbon isotope ratios $\left(\delta^{18} \mathrm{O}\right.$ and $\left.\delta^{13} \mathrm{C} ; \% \mathrm{PDB}\right)$ of planktic and benthic foraminifera were obtained from core MR16-09 PC03 at the Alfred-Wegener-Institute (AWI) in Bremerhaven, Germany. From the core PC03, 27 samples after the last glacial period were selected and up to five tests of $G$. bulloides (planktic foraminifera) were picked within the 250-315 $\mu \mathrm{m}$ size range. In addition, 19 samples were selected and up to three tests of Uvigerina spp. (benthic foraminifera) were picked up within the 250$500 \mu \mathrm{m}$ size range. The analysis of oxygen and carbon stable isotope were performed with a Thermo Finnigan MAT253 mass spectrometer connected to a Kiel IV CARBO unit. All values are reported as \%o vs. V-PDB. Calibration was done with NIST 19 and an internal carbonate standard of Solnhofen limestone, long-term reproducibility over a one-year period is $0.08 \%$ o for $\mathrm{d}^{18} \mathrm{O}$ and 0.04 for $\mathrm{d}^{13} \mathrm{C}$.

\section{X-ray Fluorescence Core Scanning}

The sediment core samples obtained in this study was scanned for elemental analysis with an ITRAX micro-Xray fluorescence (XRF) scanner at Kochi Core Center, Japan. These results of elemental composition in each core sample were used for age model reconstruction. XRF spectra were measured 
every $0.5 \mathrm{~cm}$ (exposure time: $15 \mathrm{~s}$ ) with an X-ray beam generated with a $3 \mathrm{~kW}$ Mo target (run at $30 \mathrm{kV}$ and $55 \mathrm{~mA})$.

\section{Data availability}

All relevant data are within the manuscript and Supporting Information files.

\section{Declarations}

\section{Acknowledgements}

This study used samples and data that were collected during cruise MR16-09_leg.2. We thank the crews of the R/V Mirai. This study was supported by the Japan Agency for Marine-Earth Science and Technology, Japan Society for the Promotion of Science Fellowship Grant 25-5427, 17J09017, Grants-InAid for Scientific Research (KAKENHI) Grant Numbers 15H05712, 16H04961, 24540505, Alfred Wegener Institute, and the Cluster of Excellence "The Ocean Floor-Earth's Uncharted Interface" funded by the German Research Foundation (DFG).

\section{Author contributions}

S. Iwasaki, F. Lamy and Lester Lembke-Jene analyzed samples and wrote the main manuscript text and made the figures. K. Nagashima, H. W. Arz, N. Harada and K. Kimoto also analyzed samples and reviewed this manuscript.

\section{Competing financial interests}

The authors declare no competing interests.

\section{Materials \& Correspondence}

Shinya Iwasaki (email: siwasaki@marum.de)

\section{References}

1. Barnola, J. M., D. Raynaud, Y. S. Korotkevitch, and C. Lorius, Vostok ice core: a 160,000-year record of atmospheric CO2, Nature, 329, 408-414 (1987).

2. Petit, J. R. et al. Climate and atmospheric history of the past 420,000 years from the Vostok ice core, Antarctica. Nature 399, 429-436 (1999).

3. Sigman, D. M., and E. A. Boyle, Glacial/interglacial variations in atmospheric carbon dioxide, Nature, 407(6806), 859-869, doi:10.1038/35038000 (2000).

4. Matsumoto, K. Radiocarbon-based circulation age of the world oceans. J. Geophys. Res. 112, 1-7 (2007). 
5. Gebbie, G. How much did Glacial North Atlantic Water shoal? Paleoceanography 29, 190-209 (2014).

6. Muglia, J., Skinner, L. C. \& Schmittner, A. Weak overturning circulation and high Southern Ocean nutrient utilization maximized glacial ocean carbon. Earth Planet. Sci. Lett. 496, 47-56 (2018).

7. ï»¿Sigman, D. M., Hain, M. P. \& Haug, G. H. The polar ocean and glacial cycles in atmospheric CO2 concentration. Nature 466, 47-55 (2010).

8. ï» ¿Sarnthein, M., Schneider, B. \& Grootes, P. M. of the Past Peak glacial 14 C ventilation ages suggest major draw-down of carbon into the abyssal ocean. Clim. Past 9, 2595-2614 (2013).

9. Charles, C. D. \& Fairbanks, R. G. Evidence from Southern Ocean sediments for the effect of North Atlantic deep-water flux on climate. Nature 355, 416-419 (1992).

10. Ninnemann, U. S. \& Charles, C. D. Changes in the mode of Southern Ocean circulation over the last glacial cycle revealed by foraminiferal stable isotopic variability. Earth Planet. Sci. Lett. 201, 383396 (2002).

11. ̈̈»¿Siani, G. et al. Carbon isotope records reveal precise timing of enhanced Southern Ocean upwelling during the last deglaciation. Nat Commun 4, 2758 (2013).

12. ï»¿ ¿Ronge, T. A. et al. Radiocarbon constraints on the extent and evolution of the South Pacific glacial carbon pool. Nat. Commun. 7, 1-12 (2016).

13. ї»¿Basak, C. et al. Breakup of last glacial deep stratification in the South Pacific. Science. 359, 900904 (2018).

14. ï»¿ ¿Gersonde, R., Crosta, X., Abelmann, A. \& Armand, L. Sea-surface temperature and sea ice distribution of the Southern Ocean at the EPILOG Last Glacial Maximum - a circum-Antarctic view based on siliceous microfossil records. Quat. Sci. Rev. 24, 869-896 (2005).

15. ï»¿ ¿Toggweiler, J. R., Russell, J. L. \& Carson, S. R. Midlatitude westerlies, atmospheric $\mathrm{CO}_{2}$, and climate change during the ice ages. Paleoceanography 21, 1-15 (2006).

16. Menviel, L. et al. Southern Hemisphere westerlies as a driver of the early deglacial atmospheric Co2rise. Nat. Commun. 9, 1-12 (2018).

17. Herguera, J. C., Diego, S., Berger, W. H. \& Diego, S. Evidence for a bathyal front at 2000-M depth in the glacial Pacific, based on a depth transect on Ontong Java Plateau. Paleobiology 7, 273-288 (1992).

18. Talley, L. D. Closure of the global overturning circulation through the Indian, Pacific, and Southern Oceans: Schematics and transports. Oceanography. Oceanography 26, 80-97 (2013).

19. ï»¿Skinner, L. C., Fallon, S., Waelbroeck, C., Michel, E. \& Barker, S. Ventilation of the Deep Southern Ocean and Deglacial $\mathrm{CO}_{2}$ Rise. Science. 328, (2010).

20. ї»¿ $\mathrm{Rae}, \mathrm{J}$. W. B. et al. $\mathrm{CO}_{2}$ storage and release in the deep Southern Ocean on millennial to centennial timescales. Nature 562, 569-573 (2018).

21. ï»¿Matsumoto, K., Oba, T., Lynch-Stieglitz, J., and Yamamoto, H. Interior hydrography and circulation of the glacial Pacific Ocean: Quaternary Science Reviews, 21, 1693-1704 (2002). 
22. de la Fuente, M. et al. The Evolution of Deep Ocean Chemistry and Respired Carbon in the Eastern Equatorial Pacific Over the Last Deglaciation. Paleoceanography 32, 1371-1385 (2017).

23. Yu, J. \& Elderfield, H. Benthic foraminiferal B/Ca ratios reflect deep water carbonate saturation state. Earth Planet. Sci. Lett. 258, 73-86 (2007).

24. ï»¿Allen, K. A. et al. Southwest Pacific deep water carbonate chemistry linked to high southern latitude climate and atmospheric $\mathrm{CO}_{2}$ during the Last Glacial Termination. Quat. Sci. Rev. 122, 180191 (2015).

25. Allen, K. A., Sikes, E. L., Anderson, R. F. \& Rosenthal, Y. Rapid Loss of $\mathrm{CO}_{2}$ From the South Paci fi C Ocean During the Last Glacial Termination Paleoceanography and Paleoclimatology. 1-13 (2019).

26. ï»¿Lohmann, G. P. A model for variation in the chemistry of planktonic foraminifera due to secondary calcification and selective dissolution. Paleoceanography 10, 445-457 (1995).

27. ï»¿Broecker, W. S. \& Clark, E. Glacial-to-Holocene redistribution of carbonate ion in the deep sea. Science 294, 2152-2155 (2001).

28. Barker, S. \& Elderfield, H. Foraminiferal calcification response to glacial-interglacial changes in atmospheric $\mathrm{CO}_{2}$. Science 297, 833-6 (2002).

29. Marshall, B. J., Thunell, R. C., Henehan, M. J., Astor, Y. \& Wejnert, K. E. Planktonic foraminiferal area density as a proxy for carbonate ion concentration: A calibration study using the Cariaco Basin ocean time series. Paleoceanography 28, 363-376 (2013).

30. Johnstone, H. J. H., Schulz, M., Barker, S. \& Elderfield, H. Inside story: An X-ray computed tomography method for assessing dissolution in the tests of planktonic foraminifera. Mar. Micropaleontol. 77, 58-70 (2010).

31. ï»¿Iwasaki, S. et al. Observation of the dissolution process of Globigerina bulloides tests (planktic foraminifera) by X-ray microcomputed tomography. Paleoceanography 30, 317-331 (2015).

32. ï»¿Iwasaki, S., Kimoto, K., Sasaki, O., Kano, H. \& Uchida, H. Sensitivity of planktic foraminiferal test bulk density to ocean acidification. Scientific reports 9, 1-9 (2019).

33. Iwasaki, S., Kimoto, K., Okazaki, Y. \& Ikehara, M. Micro-CT Scanning of Tests of Three Planktic Foraminiferal Species to Clarify Dissolution Process and Progress. Geochemistry Geophys. Geosystems 20, 1-15 (2019).

34. Broecker, W.S. \& Peng, T.-H. Tracers in the Sea, Eldigio Press, Palisades, NY, (1982).

35. Siani, G. et al. Late Glacial to Holocene terrigenous sediment record in the Northern Patagonian margin: Paleoclimate implications. Palaeogeogr. Palaeoclimatol. Palaeoecol. 297, 26-36 (2010).

36. Lamy, F. et al. Glacial reduction and millennial-scale variations in Drake Passage throughflow. PNAS 112, 13496-13501 (2015).

37. Berger, W. H. \& Killingley, J. S. Box cores from the equatorial pacific: ${ }^{14} \mathrm{C}$ sedimentation rates and benthic mixing. Mar. Geol. 45, 93-125 (1982).

38. ï»¿Mekik, F. A., Anderson, R. F., Loubere, P., François, R. \& Richaud, M. The mystery of the missing deglacial carbonate preservation maximum. Quat. Sci. Rev. 39, 60-72 (2012). 
39. Anderson, B. E. et al. Wind-driven upwelling in the Southern Ocean and the deglacial rise in atmospheric $\mathrm{CO}_{2}$. Science 323, 1443-1448 (2009).

40. ї»¿Duchamp-Alphonse, S. et al. Enhanced ocean-atmosphere carbon partitioning via the carbonate counter pump during the last deglacial. Nat. Commun. 9, 1-10 (2018).

41. McManus, J. F., Francois, R., Gherardi, J. \& Keigwin, L. D. Collapse and rapid resumption of Atlantic meridional circulation linked to deglacial climate changes. Nature 428, 1-4 (2004).

42. Böhm, E. et al. Strong and deep Atlantic meridional overturning circulation during the last glacial cycle. Nature 517, (2015).

43. $\mathrm{Yu}, \mathrm{J}$. et al. Last glacial atmospheric $\mathrm{CO}_{2}$ decline due to widespread Pacific deep-water expansion. Nat. Geosci. 13, 628-633 (2020).

44. ï»¿Kawabe, M. \& Fujio, S. Pacific Ocean Circulation Based on Observation. J. Oceanogr. 66, 389-403 (2010).

45. Toyos, M. H., Lamy, F., Lange, C. B. \& Jene, L. L. Antarctic Circumpolar Current Dynamics at the Pacific Entrance to the Drake Passage Over the Past 1.3 Million Years. Paleoceanogr. Paleoclimatology 35, 1-20 (2020).

46. Wu, S. et al. Orbital- and millennial-scale Antarctic Circumpolar Current variability in Drake Passage over the past 140,000 years. Nat. Commun. 1-9 (2021). doi:10.1038/s41467-021-24264-9

47. Broecker, W. S. \& Peng, T. The cause of the glacial to interglacial atmospheric $\mathrm{CO}_{2}$ change: a polar alkalinity hypothesis. Global Biogeochem. Cycles 3, 215-239 (1989).

48. Rickaby, R. E. M., Elderfield, H., Roberts, N., Hillenbrand, C. D. \& Mackensen, A. Evidence for elevated alkalinity in the glacial Southern Ocean. Paleoceanography 25, 1-15 (2010).

49. ï»¿ ï»¿ ¿Köhler, P., Fischer, H., Munhoven, G. \& Zeebe, R. E. Quantitative interpretation of atmospheric carbon records over the last glacial termination. Global Biogeochem. Cycles 19, 1-24 (2005).

50. Key, R. M. et al. A global ocean carbon climatology: Results from Global Data Analysis Project (GLODAP). Global Biogeochem. Cycles 18, 1-23 (2004).

51. ї»¿ Mccave, I. N., Carter, L. \& Hall, I. R. Glacial - interglacial changes in water mass structure and flow in the SW Pacific Ocean. Quat. Sci. Rev. 27, 1886-1908 (2008).

52. Osborne, E. B. et al. Calcification of the planktonic foraminifera Globigerina bulloides and carbonate ion concentration: Results from the Santa Barbara Basin. Paleoceanography 31. 1083-1102 (2016).

53. Marcott, S. A. et al. Centennial-scale changes in the global carbon cycle during the last deglaciation. Nature 514, 616-619 (2014).

54. Schmitt, J. et al. Carbon isotope constraints on the deglacial $\mathrm{CO}_{2}$ rise from ice cores. Science. 336, 711-714 (2012).

\section{Figures}



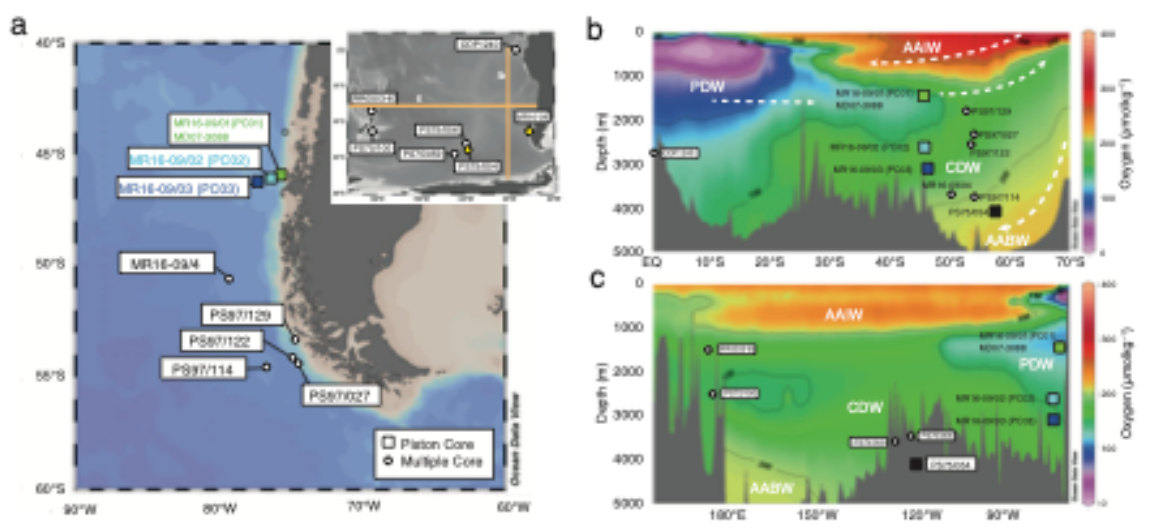

\section{Figure 1}

Core location and study area. (a) Location of piston core of MR16-09 (PC01: 46.04 ${ }^{\circ} \mathrm{S}, 75.41^{\circ} \mathrm{W} ; 1537 \mathrm{~m}$ water depth, PC02: $46.04^{\circ} \mathrm{S}, 76.32^{\circ} \mathrm{W} ; 2787 \mathrm{~m}$ water depth, PC03: $46.24^{\circ} \mathrm{S}, 77.19^{\circ} \mathrm{W} ; 3074 \mathrm{~m}$ water depth), and location of multiple cores analyzed in this study. The enlarged map shows locations of PS75/054-1 $\left(56^{\circ} \mathrm{S}, 115^{\circ} \mathrm{W}, 4085 \mathrm{~m}\right.$ ) and core sites referred in this study. (b) Cross-sections of oxygen concentration $\left(\mu \mathrm{mol} \mathrm{kg}{ }^{-1}\right)$ along $93^{\circ} \mathrm{W}$ and $30^{\circ} \mathrm{S}$ based on the data from Global Ocean Data Analysis Project (GLODAP). Distribution of water mass are shown. 

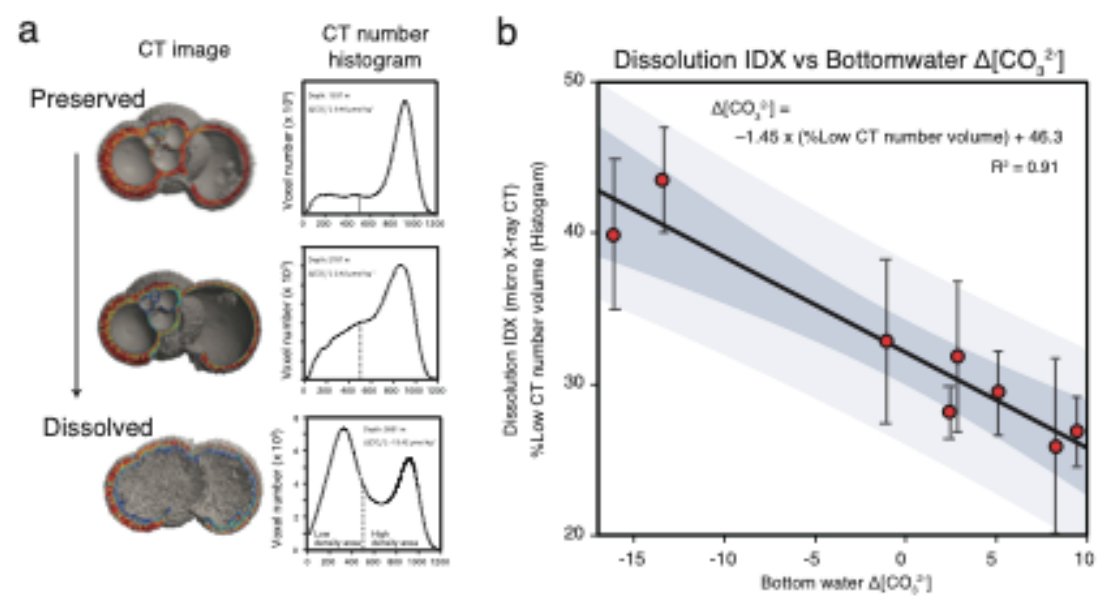

\section{Figure 2}

(a) Variations in cross section isosurface images and CT number histograms of G. bulloides tests with dissolution. Typical condition of tests is selected from each sample and shown. Tests were obtained from the three core-top samples from depths of $1537-3851 \mathrm{~m}$ in the Pacific Southern Ocean. $\Delta\left[\mathrm{CO}_{3}{ }^{2-}\right]$ at the multiple core sample sites ranged from 9.46 to $-13.42 \mu \mathrm{mol} \mathrm{kg}{ }^{-1}$, data from GLODAP. Dashed line in the CT number histograms show the threshold between low and high values. (b) Plots of \%Low-CTnumber calcite volume of $G$. bulloides tests against deep-water $\Delta\left[\mathrm{CO}_{3}{ }^{2-}\right]$ at each sampling site of 
multiple cores. Regression line and the $95 \%$ confidence interval (dark shading) and prediction interval (light shading) are shown.

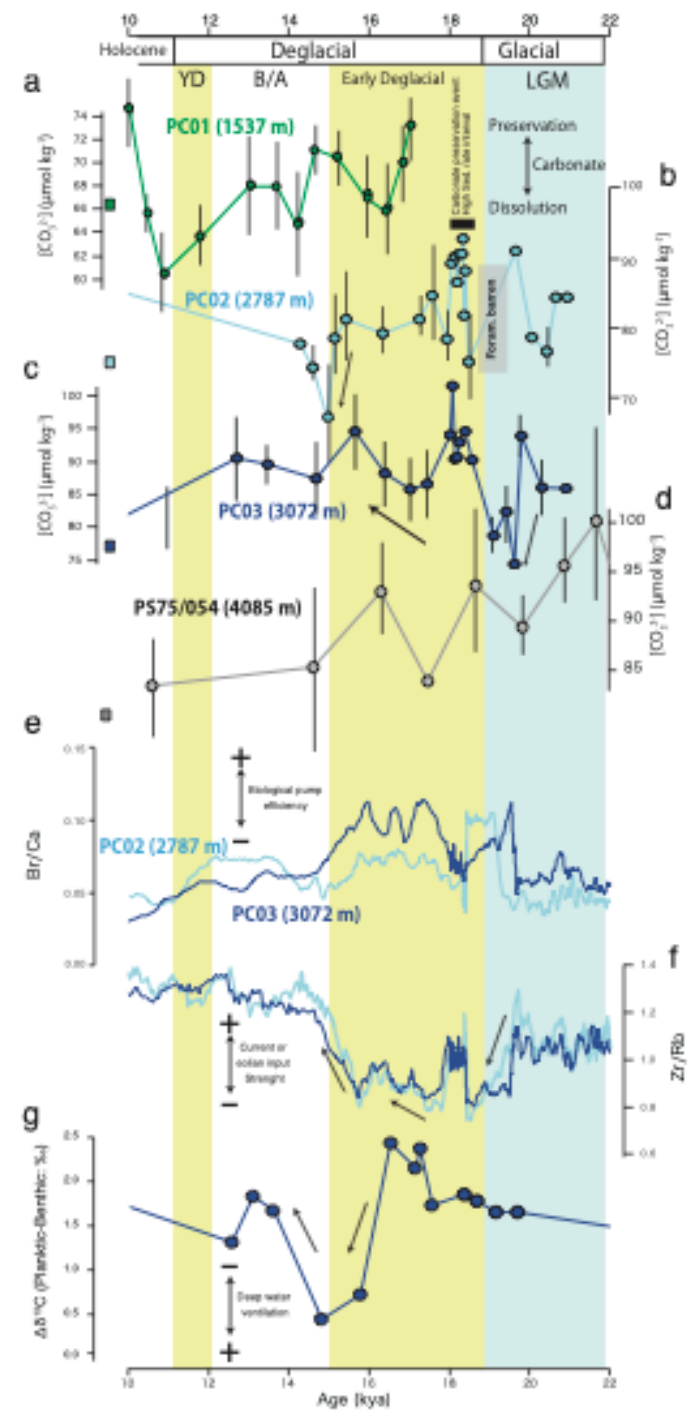

Figure 3

Reconstruction of deep-water [ $\mathrm{CO}_{3}{ }^{2}$ ] during 10-22 ka BP, (a) PC01, (b) PC02, (c) PC03 and (d) PS75/054. (e) $\mathrm{Br} / \mathrm{Ca}$, and (f) $\mathrm{Zr} / \mathrm{Rb}$ rations in PCO2 and PC03. (g) difference in stable carbon isotope ratio $\left(\Delta \mathrm{d}^{13} \mathrm{C}\right)$ between planktic and benthic foraminifera in PC03. 


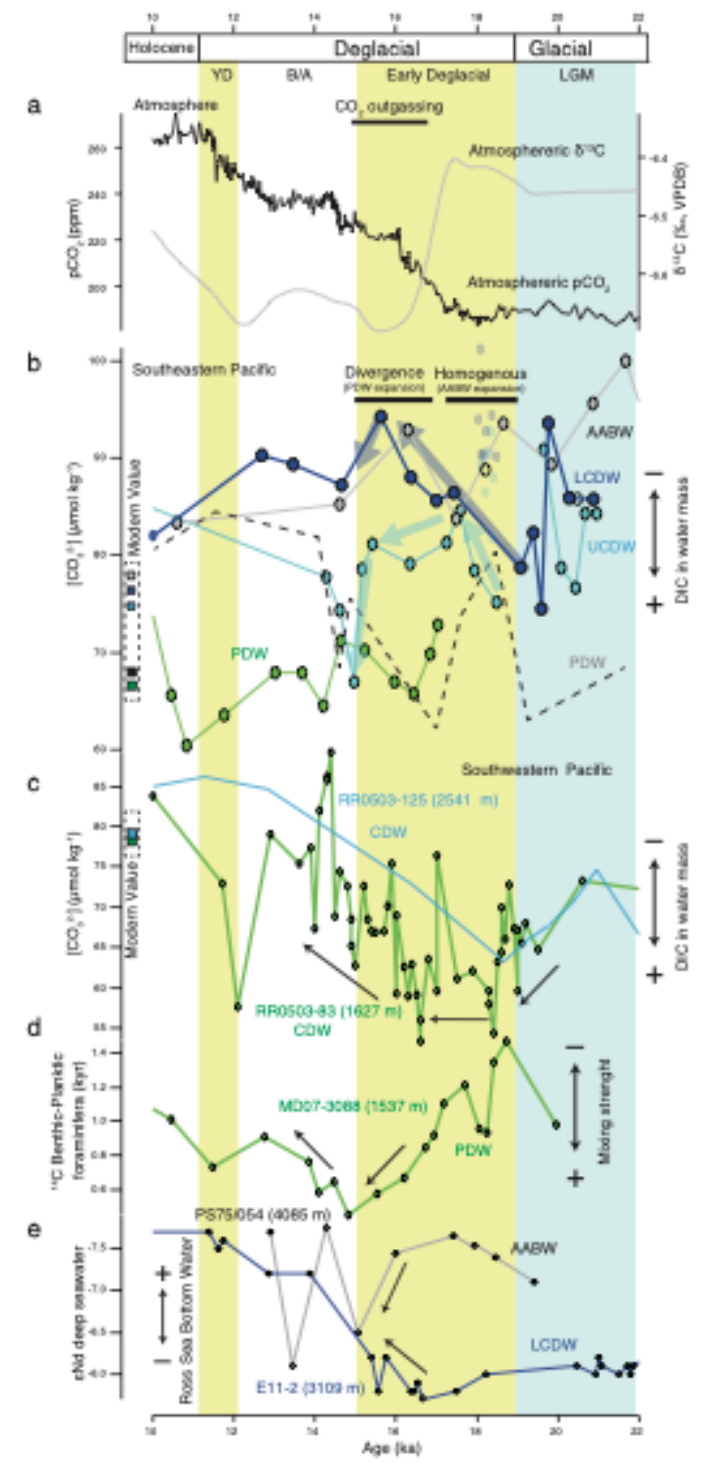

\section{Figure 4}

(a) Atmospheric $\mathrm{CO}_{2}$ concentrations ${ }^{53}$, and atmospheric $\delta^{13} \mathrm{C}$ record from Antarctic ice cores ${ }^{54}$. (b) Deepwater $\left[\mathrm{CO}_{3}{ }^{2}\right]$ based on XMCT scanning method in the SE Pacific (this study) and result from ODP1240 from the East equatorial Pacific ${ }^{22}$. (c) Deep-water $\left[\mathrm{CO}_{3}{ }^{2}\right]$ based on benthic foraminiferal $\mathrm{B} / \mathrm{Ca}$ proxy in the SW Pacific ${ }^{24,25}$. (d) Changes in the records of foraminifera benthic-planktic $14 \mathrm{C}$ age in the SE Pacific ${ }^{11}$. (e) Change in $\varepsilon N d$ of deep-water in the Southern Pacific ${ }^{13}$. 


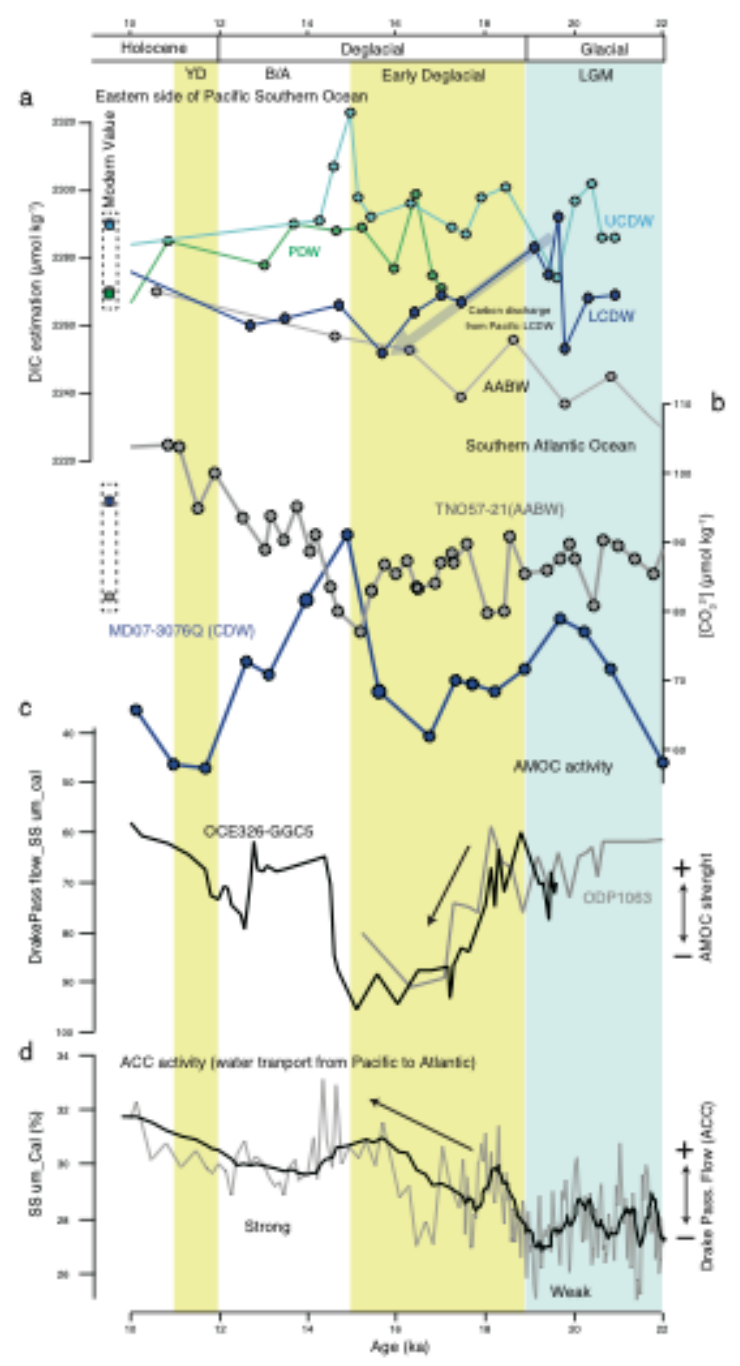

\section{Figure 5}

(a) Estimated DIC based on Deep-water $\left[\mathrm{CO}_{3}{ }^{2}\right]$ reconstruction by XMCT scanning method in the SE Pacific (this study) under the assumption of stable bottom water conditions. (b) Deep-water $\left[\mathrm{CO}_{3}{ }^{2}\right]$ based on benthic foraminiferal B/Ca proxy in the Southern Atlantic ${ }^{43}$. (c) Variance of AMOC strength shown by ${ }^{231} \mathrm{~Pa} /{ }^{230} \mathrm{Th}^{41,42}$. (d) Variance of grain size in the sediment core at the Drake Passage, represent the strength of deep-water flow ${ }^{46}$. 

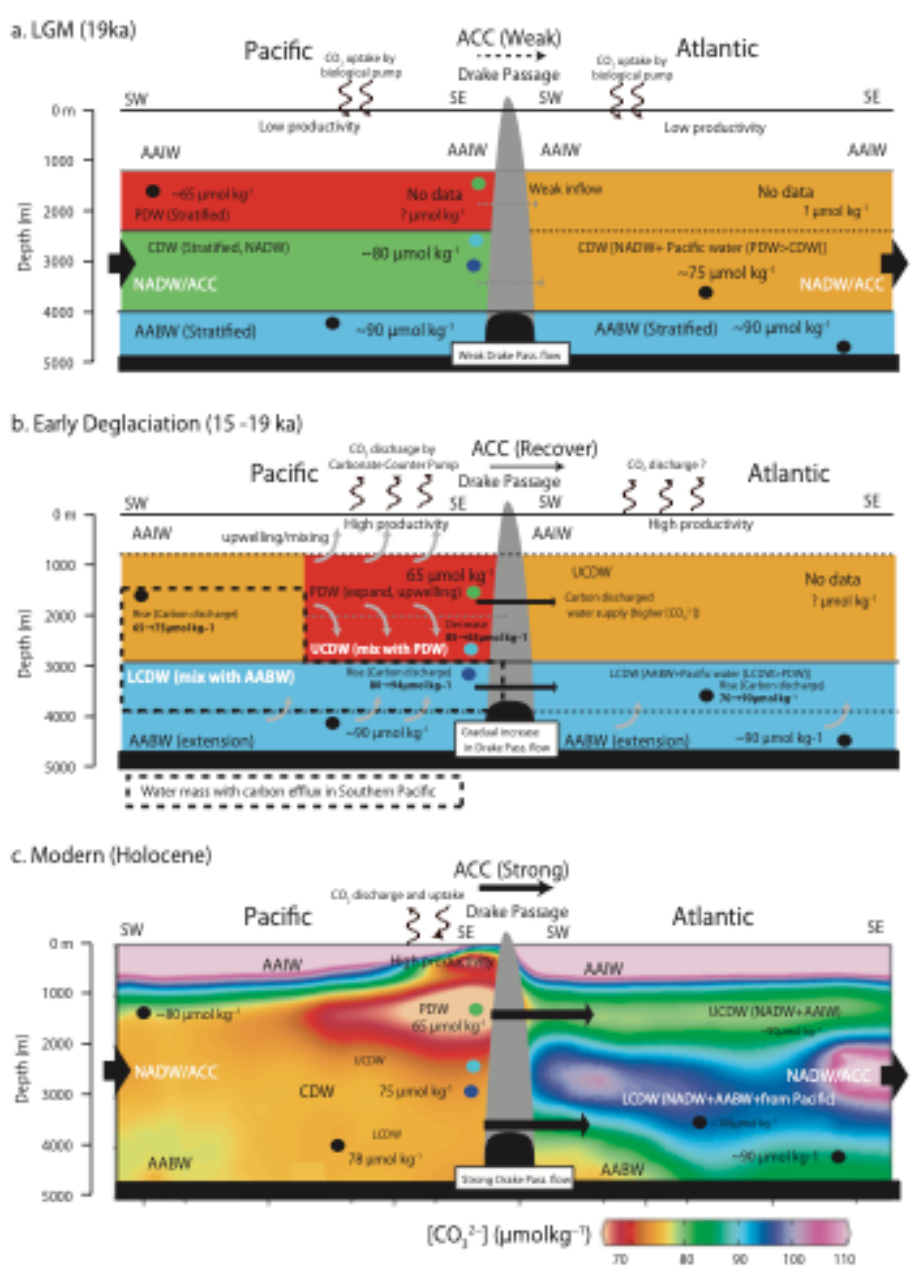

\section{Figure 6}

Schematic illustration of water column structure in the Southern Pacific and the Southern Atlantic at the end of LGM, the early deglacial, and Modern condition. (a) LGM (19 ka BP): characterized by strong deepwater stratification, weak ACC, weak Drake Passage flow and strong AMOC. (b) the early deglaciation (15 - 19 ka BP): Break up of deep-water stratification, strengthening of ACC, strengthening of Drake Passage flow and weakening or stop of AMOC. (c) Modern condition: Moderate mixing of deep-water, Strong ACC, 
Strong Drake Passage flow and strong AMOC. West-East transect of $\left[\mathrm{CO}_{3}{ }^{2-}\right]$ at around $30^{\circ} \mathrm{S}$ is based on the modern data from GLODAP.

\section{Supplementary Files}

This is a list of supplementary files associated with this preprint. Click to download.

- Multiplecoredata.xlsx

- Pistoncoreagemodel.xlsx

- Pistoncoredata.xlsx

- SupplementFigure1.pdf

- SupplementFigure2.pdf

- SupplementTable1.pdf 